DOI:10.32703/2415-7422-2020-10-2-281-292

UDC: 61(091)

\author{
Stefano Eramo \\ University of Perugia \\ Gambuli Square, 1, Perugia, Italy \\ e-mail: stefano.eramo@unipg.it \\ https://orcid.org/0000-0002-3329-9200
}

\title{
Giancarlo Barraco
}

University of Perugia

Gambuli Square, 1, Perugia, Italy

e-mail: giancarlo.barraco@unipg.it

https://orcid.org/0000-0002-4589-631X

\author{
Paolo Zampetti \\ University of Pavia \\ Avenue Brambilla, 74, Pavia, Italy \\ e-mail: paolo.zampetti@unipv.it \\ https://orcid.org/0000-0003-4399-7034
}

\section{The forgotten contribution of J. E. Purkyně to dentistry}

Abstract. Objectives: the name of Jan Evangelista Purkyně (Purkinje in German), born in Bohemia in 1787 and died in Prague in 1869, is mainly associated with discoveries in histology and specialist fields of Medicine like embriology, histological techniques, ophthalmology, cardiology and neurophysiology. This short article presents a brief account of his life, commemorates his achievements in biology and medicine but also in in the politics and literature of his Country (he was elected to the Diet of Bohemia but also he composed poems and important translations from German, French and Italian languages into Czech) and examines in depth his contribution to Dentistry. Materials and Methods: Purkynè's major contributions to Dentistry, which focused on embryology and dental histology, endodontics and periodontology, are traced to two dissertations in Latin which were discussed by his pupils (Meyer Fraenkel and Isaac Raschkow), at Breslau University in 1835: we present a brief summary of each, with the major innovative findings highlighted. Results: the two dissertations contain remarkable, though often overlooked, contributions to Dentistry. Among these we can indicate the individuation of: the dental cement (substantia ostoidea), the acquired dental pellicle, the nature of optical illusion of Hunter- 
Schreger lines, the "enamel pulp" from which the enamel would evolve, the subodontoblastic nervous plexus which is the cause of tooth sensitivity, the predentine, the organic nature of the process of enamel formation, the dentine and enamel formation in opposing directions, the presence of alveolus membrane (id est: the periodontium). Conclusions: after reviewing the main innovations these two dissertations made to Dentistry, Purkynè's personal share in both is very clear. Both the two his pupils acknowledged their debt to Purkyne and also famous contemporary Purkinje scientists such as Alexander Nasmyth, Sir Richard Owen, Sir James Paget had no doubt he is had generated the ideas expressed in the two little treatises.

Keywords: History of dentistry; Raschkow; subodontoblastic plexus; teeth

\section{Introduction.}

J. E. Purkyně (Fig. 1) was born into a catholic family in Libochovice (Bohemia in the Austrian-Hungarian Empire, today's Czech Republic) on 18th December 1787. His father died in 1793. J. E. was educated at his local, Czech language primary school (Anonymous, 1870; Henry, 1953) and then from 1797 until 1804 at the Piarist Fathers secondary school in southern Moravia. There he learned German, Latin, French and Italian and entered the Piarist Order as a novice (Henry, 1953; Posner, 1969; Sykora, 1988) but decided against taking his vows in 1807. He started working as a private tutor in Prague while studying at Prague University faculty of philosophy. He began his studies in medicine in 1812, graduating in 1818 from Prague University with a dissertation entitled «A contribution to knowledge about subjective sight» (Purkinje, 1819). He was appointed assistant professor of anatomy at the university, a post he held for five years before moving in 1823 to the Royal Prussian University of Breslau (now Wrocław, Poland) where he worked as professor of physiology and pathology until 1850.

Dr. Purkyně married Julia Rudolphy in 1827, daughter of a professor of physiology in Berlin. From 1829 to 1834 they had four children: Rosalia and Johanna who died of scarlet fever in 1832 (Henry, 1953), Emmanuel, who became a professor of botany and karel, who was destined to be one of the Czech Republic's most famous painters, dying in 1868. When Julia succumbed to meningitis in 1835 (Henry, 1953), J.E. was left a widower with two children under the age of four. Despite these family tragedies, which he bore with Job-like patience, the years he spent at Breslau were among his most prolific. He founded the physiology institute, acquired the highly advanced Plössl microscope and published many of his ideas in his pupils' dissertations. In 1850 he was appointed professor of physiology at Prague University, a post he held until his death in 1869.

He founded «Živa» (Life), a Czech scientific journal in 1853, was elected to the Diet of Bohemia for the 1861-1866 legislature and was awarded the austrian imperial order of Leopold in recognition of his scientific achievements in 1868 (Szpilczynski, 1971; Jay, 2000). After a short illness, he died in Prague in 1869, at the age of 82. He 
received a state funeral and is buried in Prague's «Vyšehrad» monumental cemetery, which is reserved for the Czech Republic's most prominent citizens.

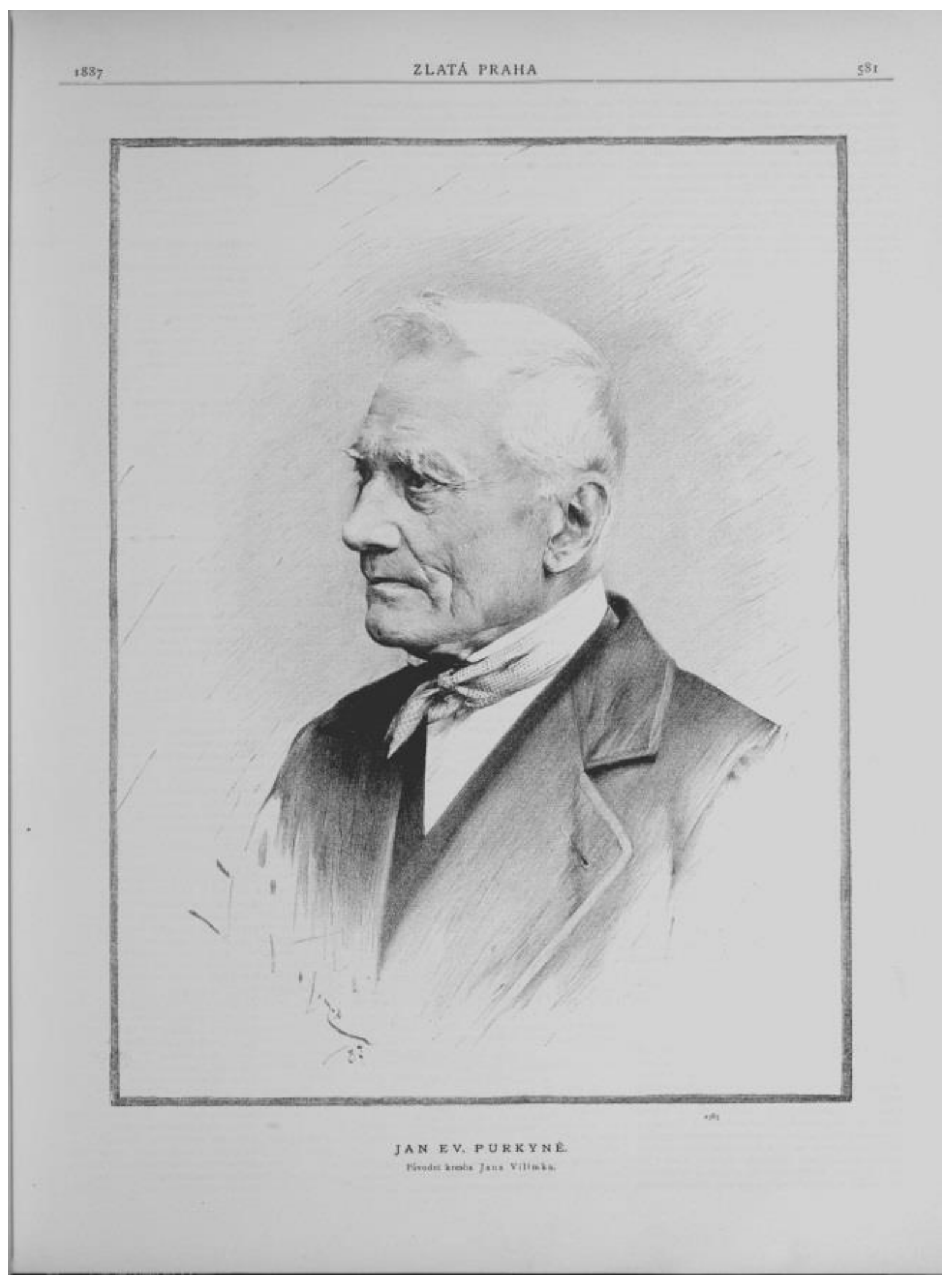

Figure 1. Jan Ev. Purkyně. Drawing by Jan Vilímek (Vilímek, 1887). 


\section{Purkyně's main innovations in biology and medicine.}

Summarizing Purkyně's many discoveries is not easy, due to his wide range of interests and, according to one of his pupils, his habit of «passing from one discovery to the next, leaving the task of working out details to others» (Eiselt, 1859; Cavero, Guillon, \& Holzgrefe, 2017). Vision was among his earliest and most constant interests, as shown by his graduation dissertation. According to Purkyně, diverse ocular properties and structures could be investigated psychologically and physiologically, the latter by means of careful analysis of microscopy findings (Anonymous, 1870). In 1820 he published a paper on vertigo (Purkinje, 1820) and one year later, a wideranging work on the psychology of dreams (Cavero, Guillon, \& Holzgrefe, 2017). After moving to Breslau his inaugural lecture on the structure of the retina appeared in print in 1823 (Purkinje, 1823) and was followed by an innovative contribution to advancing knowledge of subjective vision in 1825 (Purkinje, 1825) as well as an original contribution to music acoustics (Cavero, Guillon, \& Holzgrefe, 2017). Afterwards (1825-1833) he focused his attention on animal embryology and plant histology, identifying the germinal vesicle in a paper on embryology in bird's eggs (Purkinje, 1830a). His work on plant pollens (Purkinje, 1830b) won him the Montyon prize medal from the Institute of France (Anonymous, 1870). In 1836 Purkyně and G. G. Valentin, his assistant who would later become professor of physiology in Berne University, published a major paper on mammal, bird and amphibian genital and respiratory ciliated epithelia, correctly claiming they served to defend the organism from foreign substances (Purkynje \& Valentin, 1836). This was followed, two years later in 1838 by a report that was co-authored with $\mathrm{S}$. Pappenheim exploring in vitro tissue digestion by gastric juices (Purkinje \& Pappenheim, 1838). In the meantime from 1824 until 1845, he had started publishing on a wide range of research topics in his pupils' dissertations, thus bestowing honours on them. These included: theory of vertigo after brain trauma, human skin histology, identification of sweat glands and their ducts, bone histology, embryology and tooth histology, cartilage histology, blood vessel histology, female genital embryology, heart muscle histology, uterus histology, granular nerve formation defining protoplasma, the nerve complex in spinal cord pia mater and cerebrospinal fluid histology. When Purkyně's wide range of publications were all collected in his 12 volumes of Opera Omnia (Purkinje, 1919-1985) so many great innovations emerged that contemporary scientists conferred his name on them. Hence in embryology there is Purkyné's Vesicle which is the germinal vesicle in the egg (Purkinje, 1830a). In ophthalmology one has the Purkyně Effect (how colour perception varies with environmental light), Purkyně's Images (projection of a light angled at $30^{\circ} / 50^{\circ}$ generates four reflected images of different eye areas) and Purkyně's Tree (self visualization of retinal blood vessels under certain light conditions) (Wade \& Brožek, 2001). In cardiology there are Purkyně's Fibres in the heart conduction system (Schweitzer, 1991; Davies \& Hollman, 1996). In neurophysiology Purkyně's cells are found in the cerebellum (Haas, 1994). Purkyně's compressorium was used in histological techniques (Purkinje, 1834). However, many of his other 
discoveries or major contributions such as new techniques for including and fixing cells in for histological analysis or the development of the first microtome were not named after him.

\section{Purkyně and dentistry.}

Purkyně's major contributions to dentistry, which focused on embryology and dental histology, endodontics and periodontology (Cox et al., 2017; Foster, 2017), are traced to two dissertations in Latin which were discussed at Breslau University in 1835. The first, by Meyer Fraenkel, was entitled «De penitiori dentium humanorum structura observations» (Fraenkel, 1835), while the second, by Isaac Raschkow, was «Meletemata circa mammalium dentium evolutionem» (Raschkow, 1835). Here's a brief summary of each, with major innovative findings highlighted in italics.

M. Fraenkel's dissertation "Observations on the structure of human teeth», consisted of 20 pages (plus 2 pages of explanations and 8 figures) containing 26 sections, and was histology based.

After a general presentation, he stated he would illustrate what was known and then his research $(\S 1)$. He then described tooth anatomy, crown, the cemento-enamel junction and root/s $(\$ 2)$, the diverse functions of different teeth (incisors, canines etc) (§3), the differences between primary and permanent teeth (§4), dental pulp (§5), tooth sockets and gums (\$6). He moved on to discuss dental substances in general (enamel substantia adamantina and dentine- substantia dentalis propria), proving in 7 very clear steps that teeth could not be classified as bone $(\$ 7)$ and were not horns $(\$ 8)$. He then introduced the concept of substantia ostoidea which, as it covered the roots, can be identified as dental cement ( $\$ 9)$. He refuted Hunter's statement that caries attacked the root more slowly than other tooth parts $(\S 10)$. He described the general modality for the chemical preparation of teeth for dissection. Although he emphasized that after the mineral tooth surface had been dissolved in acid, «a very fine membrane-type substance» was observed at microscopy, he did not list its features. This might today be identified as an acquired pellicle. He also highlighted the importance of using the Plössl microscope $(\$ 11)$ and presented the materials and methods for observing dentine under the microscope $(\$ 12)$.

Sections 13-19 focused on dentine: its sinuous, tubular structure and the presence of a thin membrane (odontoblasts layer?) at the pulp border ( $\$ 13)$; the tubule pattern in individual teeth (\$14); longitudinal and cross sections of the tubule cavities ( 115$)$. Then he commented and expounded on Schreger lines in dentine (which are also found in animal tusks) (\$16-17) and the reddish colour of dentine that Hunter had observed in animal teeth $(\S 18)$. He reported the Hunter, Blake, Heusinger, Weber and Van Kaathoven descriptions of dentine (\$19).

Sections 20-26 were dedicated to tooth enamel. Many scientists had described enamel as fibrous in nature. The Hunter, Blake and Schreger definitions of enamel were cited and Hunter's observation of fine striae on the enamel was confirmed. He insisted the fibres were mineralized $(\$ 20)$ and stated that a clear view of the enamel structure 
could only be obtained by observing different sections on five planes following the fibre/prism patterns, which were illustrated in fine images. The planes included the longitudinal (which led him to define the Hunter-Schreger lines as an optical illusion); oblique $(\$ 21-22)$; parallel to the surface $(\$ 23)$; parallel to the surface but closer to the dentine $(\$ 24)$ and the crown cross-section (\$25). Finally, he summarized findings of his research into fibre/prism patterns and concluded by saying only excellent mathematicians could explain the reason for such complexity $(\$ 26)$. The reference list contained 48 citations.

Isaac Raschkow's dissertation, entitled «Essays on mammal tooth evolution», consisted of 20 pages (plus 2 pages of legends to the figures and 1 page of figures). Set out in 62 sections, it focused on embryology. Raschkow reported his own findings in the first part of his dissertation $(\$ 1-35)$ and compared them with previous publications in the second (\$36-62).

After a general introduction, he stated that he would first present his own observations and then compare them with previous reports $(\S 1)$; He described the dissection methods to obtain dental follicles in diverse animal species $(\$ 2-3)$ the dental follicle in general (\$4-5); follicle contents and the tooth germ, in which he identified a globular nucleus. This he designated the «adamantine organ» from which the enamel would evolve (\$6-8). He described the evolution of the enamel organ $(\S 9)$ showing that it contained a stellate reticulum which he denominated enamel pulp $(\$ 10)$. Careful observation of the internal surface of the adamantine membrane (\$11) showed it was composed of «hexagonal cells» (ameloblasts?) (\$12). He claimed he had found small differences in the adamantine membrane in ruminants, swine and rodents $(\S 13)$.

He continued with an in-depth description of the tooth germ $(\S 14)$, stating it was connected to the nerve from its beginning and hypothesizing it might originate from it (§15-16). In describing the dental pulp he identified the sub-odontoblastic nervous plexus which accounted for extreme tooth sensitivity $(\$ 17)$. He reported he had observed «massae lapidosae» (pulp stones?) in the dental pulp of hares, swine and deer (§18). He identified a basal membrane around the pulp which he named the «maembrana praeformativa» ( $\$ 19)$. He described equal-sized globular grains (cells) as constituting the parenchyma that would form the dentine $(\$ 20)$, noting they were positioned in much greater order near the preformative membrane ( odontoblastic layer»?) (\$21). He observed the dental germ was more evolved when the substantia dentalis (dentine) started to form, beginning at the coronal apex and passing through the tooth body to the roots. Very early stage dentine was soft and easily detached (predentine?). Growth direction proceeded from the outside in, reducing pulp space ( 22 24). At the end of tooth growth he observed root canals and apical foramen which serve for blood vessel and nerve entrance into the tooth. Since they may be single or multiple doubts were raised as to whether the osteoid layer covering the roots (denominated cement in equidae and ruminants) was generated from the pulp (\$25). He then described enamel formation which he claimed was an organic process and not simply crystal precipitation, as had hitherto been believed (\$26). He stated that enamel was 
deposited in cross-section layers and reported he had observed the adamantine membrane secrete an organic sap which, probably by means of organic chemistry processes, combined with the inorganic substance to form enamel (\$27). In accounting for prisms curvature he hypothesized that the adamantine membrane, which was present before prism development, must have been curved. He differentiated between teeth with a limited enamel growth (crown) and those with unlimited growth, such as found in rodents. He admitted further in-depth studies were needed as he had observed enamel layout varied with the type of teeth and animal species. After identifying two principal directions of tooth movement as they met for chewing he observed that since movement was perpendicular in carnivores, frugivore animals and insect-eaters and horizontal in ruminants, rodents and some pachyderms, enamel quantity was greatest in the occlusal zone in the former species and in the parietal area in the latter. This finding was valid for molars but less so for canines and incisors whose function was always the same in all species. Further studies would show if these differences were to be found in the enamel organ (\$28). He noted that dentine and enamel formed in opposing directions. Dentine formed from the outside in i.e. from the periphery towards the centre while enamel formed from the inside out i.e. from the centre towards the periphery. Dentine formation was more organic while enamel formation was more mineralized. He refuted the argument that enamel formation was pure crystallization as that would prevent prisms curvature served an organic function (\$29).

He then addresses the issue of cement formation ( $\$ 30)$, hypothesizing that once the enamel had been formed, the enamel pulp changed its functions. In order to become the cement forming organ, it transformed into periosteu since the structures of bone and cement were similar (\$31). He then discussed the alveolus membrane (the periodontium), comparing it with cement stating it was like lung parenchyma, defining it as elastic and flexible and hypothesizing that it served to provide the tooth with greater mobility ( $\$ 32)$. He moved on to gum evolution ( $\$ 33)$, stating immediately that gum was not cartilage as many believed. Histological findings showed it was composed of an epithelial layer which was covered by «polyedricis squamulis» (keratinocytes?) and by a mucous membrane. Underneath was a hard parenchyma with fibrous filaments and blood vessels (lamina propria?). He had observed the already identified Serres glands or pearls (\$34). The epithelium was denser in the early stages of evolution and could easily be detached from the mucous membrane. Within the epithelium he observed there were globular cells which, when ruptured, were shown to contain lymph fluid which he speculated could become polyhedric squamules ( $\$ 35)$.

In sections 36 to 61 he compared his findings with other reports, particularly by Cuvier, Dietrichs, Burdach, Blake, Hunter, Herissant and Arnold.

\section{Conclusions.}

After reviewing the main contributions these two dissertations made to dentistry, Purkyně's personal share in both remains to be established. His two pupils went on to have respectable careers in medicine but never published anything more (Grätzer, 
1889). Both acknowledged their debt to Purkyně. Raschkow wrote in the Preface to his dissertation: (...) I would have given up if the illustrious professor Purkinje, such a supremely eminent man, had not guided and assisted me as my teacher with his heartfelt generosity and the power of his intellect. He showed me unknown regions under the microscope and although I was often doubtful and uncertain in these unexplored fields, he never ceased from helping me with facts and advice. He himself, in a generous gesture, drew the figures that illustrated my observations, which I then decided to engrave as prints (...). In his Preface Fraenkel wrote: «I don't deny I was terrified at the difficulties my task presented and I was afraid of being accused of being too audacious. The illustrious Prof. Purkinye encouraged me and promised to help me. He's a man who knows a lot, is highly intelligent and extremely precise in his research. $\mathrm{He}$ is admired for his kindness, generosity and humanity towards all, particularly his pupils. He helped me even more than he had promised. He not only got me everything I needed for this dissertation but also stopped me from making mistakes which is easy to do when making this type of observations, as he generously intervened in some of them» (...).

Above all, Purkinye's contemporaries had no doubt he had generated the ideas expressed in the two dissertations. Alexander Nasmyth wrote in 1839: «Researches on the structure of the teeth by Purkinje have lately been given to the world in a dissertation by one of his pupils (Fraenkel, 1835; Nasmyth, 1839). Sir Richard Owen wrote in 1840: «The results of the laborious investigations of this most original and indefatigable observer (Purkinje) were published, as is the custom in many German Universities, in two inaugural thesises, the one by Fraenkel (...); the other by Raschkow (...); both of which were defended in the University of Breslau in the month of October, 1835» (Owen, 1840). Sir James Paget wrote in 1842: «In no organs have the results of recent microscopic researches been so unexpected or so brilliant as in these. They have revealed structure before unknown in each of the three component parts of the tooth» and «the chief discoveries were made coincidently by Purkyně, of Breslau, and Retzius of Stockholm»? ? The former published his observation in 1835 in the dissertation of Fraenkel (...) and of Raschkow (...) (Paget, 1842).

\section{References}

Anonymous. (1870). Johann Evangelista Purkinje - obituary. Proceedings of the Royal Society of Medicine, 19, IX-XII.

Cox, C. F., Yamaguchi, H., Suzuki, S., Akimoto, N., Ruby, J. D., Maeda, N., \& Momoi, Y. (2017). How histology enriched endodontics as a specialty \& nurtured pulp biology: our endodontic continuum from 1528 into the 1900's - Part I. Dental, Oral and Craniofacial Research, 6, 1-9. https://doi.org/10.15761/DOCR.1000226

Cavero, I., Guillon, J. M., \& Holzgrefe, H. H. (2017). Reminiscing about Jan Evangelista Purkinje: a pioneer of modern experimental physiology. Advances in 


\section{Physiology \\ Education, \\ https://doi.org/10.1152/advan.00068.2017}

41(4),

$528-538$.

Davies, M. K., \& Hollman, A. (1996). Jan Evangelista Purkinje (1787-1869). Heart, 76(4), 311. https://dx.doi.org/10.1136\%2Fhrt.76.4.311

Eiselt, T. (1859). Purkyněs Arbeiten. Eine literarhistorische Skizze (1818-1859). Vierteljahrschrift fur die Praktische Heilkunde, 16(3), 1-20.

Foster, B. L. (2017). On the discovery of cementum. Journal of Periodontal Research is, 52(4), 666-685. https://doi.org/10.1111/jre.12444

Fraenkel, M. (1835). De penitiori dentium humanorum structura observations. Pressburg: Diss Vratislaviae.

Grätzer, J. (1889). Lebensbilder hervorragender schlesischer Ärzte aus den letzten vier Jahrhunderten. Breslau: Schottlaender.

Henry, J. J. (1953). Jan Evangelista Purkyně Czech scientist and patriot (1787-1869). Journal of the Royal Society of Medicine, 46(11), 933-940. https://doi.org/10.1177/003591575304601108

Jay, V. (2000). The extraordinary career of Dr. Purkinje. Archives of pathology \& laboratory medicine, 124(5), 662-663. https://doi.org/10.1043/00039985(2000)124\%3C0662:TECODP\%3E2.0.CO;2

Haas, L. F. (1994). Jan Evangelista Purkinje (1787-1869). Journal of neurology, neurosurgery, and psychiatry, 57(7), 777. https://doi.org/10.1136/jnnp.57.7.777

Nasmyth, A. (1839). Researches on the developement, structure, and diseases of the teeth. London: Churchill.

Owen, R. (1840). Odontography or a treatise on the comparative anatomy of the teeth; their physiological relations, mode of development, and microscopic structure, in the vertebrate animals. London: Bailliere.

Paget, J. (1842). Report on the chief results obtained by the use of the microscope in the study of human anatomy and physiology. London: Churchill.

Posner E. (1969). J. Evangelista Purkyně (1787-1869). British medical journal, 3(5662), 107-109. https://doi.org/10.1136/bmj.3.5662.107

Purkinje, J. E. (1919-1985). Opera omnia (Sebrané spisy) (Vol. 1-13). Praha: Academia.

Purkinje, J. E. (1819). Beiträge zur Kenntniss des Sehens in subjectiver Hinsicht. Dissertation, Prague.

Purkinje, J. E. (1820). Beiträge zur näheren Kenntnis des Schwindels aus heautognostischen Daten. Medizinische Jahrbüchern des Oesterreichisches Staates, 6(2), 79-125.

Purkinje, J. E. (1823). Commentatio de examine physiologico organi visus. Vratislaviae: W. Junk.

Purkinje, J. E. (1825). Beobachtungen und Versuche zur Physiologie der Sinne. Neue Beiträge zur Kenntniss des Sehens in subjektiver Hinsicht. Berlin: G. Reimer.

Purkinje, J. E. (1830a). Symbolae ad ovi avium historiam ante incubationem. Lipsiae: L. Voss. 
Purkinje, J. E. (1830b). De cellulis antherarum fibrosis, nec non De grano rum pollinarium formis, commentatio phytotomica. Vratislaviae: J. D. Gruson.

Purkinje, J. E., \& Valentin, G. G. (1835). De phaenomeno generali et fundamentali Motus vibratorii continui in membranis cum externis tum internis animalium plurimorum et superiorum et inferiorum ordinum obvii. Wratislaviae: L. Freund.

Purkinje, J. E., \& Pappenheim S. (1838). Vorläufige Mittheilungen aus einer Untersuchung über künstliche Verdauung. Archiv für Anatomie, Physiologie und Wissenschaftliche Medicin, 1-14.

Purkinje, J.E. (1834). Der microtomische Quetscher, ein bei microscopischen Untersuchungen unentbehrliches Instrument. Archiv für Anatomie, Physiologie und Wissenschaftliche Medicin, 385-391.

Raschkow, I. (1835). Meletemata circa mammalium dentium evolutionem. Vratislaviae: M. Friedlaender.

Schweitzer, P. (1991). Jan Evangelista Purkinje (Purkině). Clinical cardiology, 14(1), 85-86. https://doi.org/10.1002/clc.4960140119

Sykora, O. (1988). Jan Evangelista Purkyně (1787-1869): physiologist, literary figure, statesman and pioneer dental morphologist. Bulletin of the history of dentistry, $36(1), 1-7$.

Szpilczynski, S. (1971). Johann Evangelista Purkyně's contribution to the advance of the natural science and medicine. Organon, 8, 199-205.

Vilímek, J. (1887). Jan Ev. Purkyně. Zlatá Praha, 4(37), 581.

Wade, N. J., \& Brožek, J. (2001). Purkinje's vision: The dawning of neuroscience. London: Psychology Press.

\section{Стефано Ерамо}

Університет Перуджі, Італія

\section{Джанкарло Баррако}

Університет Перуджі, Італія

\section{Паоло Зампетті}

Університет Павії, Італія

\section{Забутий внесок Я. С. Пуркинє в стоматологію}

Анотація. Мета: ім'я Яна Євангеліста Пуркинє (німецькою мовою Пуркіньє), який народився в Богемії в 1787 роичі і помер у Празі в 1869 роиі, в основному пов'язане з відкриттями в гістологї̈ та спеціалізованих областях медицини, таких як ембріологія, гістологічні методи, офтальмологія, кардіологія та нейрофізіологія. Ця коротка стаття представляє невеличкий звіт про його життя, згадує його досягнення в біології та медицині, а також у політиці та літературі своєї країни (він був обраний до Сейму Богемії, але 
також він складав віриі та важливі переклади з німецьької, франиузької та італійської мови на чеську), $і$ детально вивчає його внесок у стоматологію. Матеріали та методи: основний внесок Пуркине в стоматологію, який зосереджувався на ембріологї та стоматологічній гістології, ендодонтії та пародонтологіі, простежується у двох дисертаціях латинською мовою, які захищзали його учні (Мейер Фраенкель та Ісаак Рашков) в Університеті Бреслау в 1835 роиі: ми представляємо короткий огляд кожної з них з висвітленнням основних інноваційних висновків. Результати: дві дисертації містять неабиякі, але нажаль забуті внески у стоматологію. Серед ичих внесків ми можемо вказати наступні дослідження: зубного ијементу (substantia ostoidea), утворення зубного нальоту, характеру оптичних ілюзій смуг Гунтера-Шрегера, “емалевої пульпи”, з якої емаль розвиватиметься, субодонтобластичного нервового сплетіння, яке є причиною чутливості зубів, предентину, органічної природи процесу утворення емалі, дентину і утворення емалі в протилежних напрямках, наявності мембрани альвеоли (наприклад, періодонт). Висновки: після розгляду основних нововведень, які ці дві дисертацї внесли в стоматологію, рівень особистоїучасті Пуркинє в обох стає очевидним. Обидва його вихованці визнали свій борг перед Пуркинє, а також відомі сучасні вчені, такі як Олександр Насміт, Сер Річард Оуен, Сер Джеймс Педжет, які не сумнівалися, щуо він був авторм ідей, висловлених в ичих двох маленьких трактатах.

Ключові слова: історія стоматологї; Рашков; субодонтобластичне сплетення; зуби

\section{Стефано Эрамо}

Университет Перуджи, Италия

\section{Джанкарло Баррако}

Университет Перуджи, Италия

\section{Паоло Зампетти}

Университет Павии, Италия

\section{Забытый вклад Я. Е. Пуркине в стоматологию}

Аннотация. Цель: имя Яна Евангелиста Пуркине (на немецяком языке Пуркинье), который родился в Богемии в 1787 году и умер в Праге в 1869 году, в основном связано с открытиями в гистологии и специиаличрованных областях медицины, таких как эмбриология, гистологические методы, офтальмология , кардиология и нейрофизиология. Эта короткая статья представляет небольшой отчет о его жизни, вспоминает его достижения в биологии $u$ медицине, а также в политике и литературе своей страны (он был избран в Сейм Богемии, но также он сочинял стихи и выполнил важные переводы с 
немецкого, французского и итальянского языка на чешский), и детально изучает его вклад в стоматологию. Материалы и методы: основной вклад Пуркине в стоматологию, который сосредоточен на эмбриологии и стоматологической гистологии, эндодонтии и пародонтологии, прослежсивается в двух диссертациях на латинском языке, которые защуищали его ученики (Мейер Фраенкель и Исаак Рашков) в Университете Бреслау в 1835 году: мь представляем короткий обзор каждого из них с приведением основных инновационных выводов. Результать: две диссертации содержат значительные, но к сожалению забытые открытия в стоматологии. Среди них мьл можем указать следующче исследования: зубного ичемента (substantia ostoidea), образование зубного налета, характера оптических иллюзий полос Гунтера-Шрегера, "эмалевой пульпьи", с которой эмаль развивается, субодонтобластичного нервного сплетения, которое является причиной чувствительности зубов, предентина, органической природь прочесса образования эмали, дентина и образования эмали в противоположных направлениях, наличия мембраны альвеоль (например, периодонт). Выводы: после рассмотрения основных нововведений, которые эти две диссертации внесли в стоматологию, уровень личного участия Пуркине в обоих становится очевидным. Оба его воспитанника признали свой долг перед Пуркине, а также известные современные ученые, такие как Александр Несмит, сэр Ричард Оуэн, сэр Джеймс Пэджет, не сомневались, что он был авторм идей, высказанных в двух маленьких трактатах.

Ключевые слова: история стоматологии; Рашков; субодонтобластическое сплетение; зубы

Received 21.09.2020

Received in revised form 22.11.2020

Accepted 06.12.2020 